\title{
Moral Analysis in the Videos of Dongeng Kita Channel and Its Relevance to Indonesian Learning
}

\author{
Sugeng Santoso, Ni Luh Putu Rastiti Era Agustini², Ade Asih Susiari Tantri3
}

DOI: $10.35445 /$ alishlah.v13i1.441

\begin{abstract}
Article Info
Abstract

Keywords:

Dongeng Kita

Folklore

Learning

Moral

This research aims to analyze the moral values in folklore videos on the Dongeng Kita Youtube channel and analyze its relevance to Indonesian learning in schools. The approach of this research is qualitative research, with a descriptive type. There are six video samples taken from the Dongeng Kita channel. The moral analysis is conducted by observing the sample videos and describing it according to theory, while relevance analysis is done by reviewing the applicable learning syllabus. The research found that the videos contained moral values of respect for others, not being disobedient to parents, being honest, not being lazy, not being bad, not being greedy, keeping promises, and not cheating. Besides, moral values were found to have relevance in Indonesian learning for the grade VII of Junior High Schools because the moral values can support the use of the Dongeng Kita channel as a learning media that is linear with the learning competencies of the 2013 Curriculum, which aims to develop student moral. It is expected that Indonesian teachers in schools will take advantage of the Dongeng Kita channel as a learning media to make learning more enjoyable.
\end{abstract}

Kata kunci:

Cerita rakyat

Dongeng Kita

Moral

Pembelajaran

\begin{abstract}
Abstrak
Penelitian ini bertujuan untuk menganalisis nilai moral pada cerita rakyat kanal Youtube Dongeng Kita, serta menganalis relevansinya dengan pembelajaran Bahasa Indonesia di sekolah. Pendekatan yang digunakan adalah penelitian kualitatif, dengan jenis deskriptif. Sampel video yang diambil dari kanal Dongeng Kita berjumlah 6 video. Analisis nilai moral akan dilakukan dengan cara mencermati sampel video dan menjabarkannya menurut teori, sedangkan analisis relevansi dilakukan dengan cara meninjau silabus pembelajaran yang berlaku. Dari penelitian yang dilakukan, didapatkan hasil bahwa video-video yang dianalisis mengandung nilai moral menghargai orang lain, tidak durhaka, jujur, tidak malas, tidak berbuat jahat, tidak serakah, menempati janji, dan tidak berbuat curang. Selain itu, nilai-nilai moral yang ditemukan memiliki relevansi dengan pembelajaran Bahasa Indonesia kelas VII Sekolah Menengah Pertama, karena nilai moral yang terkandung dapat mendukung penggunaan video kanal Dongeng Kita sebagai media pembelajaran yang sejalan dengan kompetensi pembelajaran Kurikulum 2013, yang bertujuan mengembangkan moral siswa. Para guru Bahasa Indonesia di sekolah diharapkan memanfaatkan keberadaan kanal Dongeng Kita sebagai media pembelajaran agar pembelajaran menjadi lebih menyenangkan.
\end{abstract}

\footnotetext{
${ }^{1}$ Universitas Pendidikan Ganesha, Singaraja, Indonesia

Email: sugengsantoso18@undiksha.ac.id

${ }_{2}^{2}$ Universitas Pendidikan Ganesha, Singaraja, Indonesia

Email: niputurastitieraaagustini22@undiksha.ac.id

3 Universitas Pendidikan Ganesha, Singaraja, Indonesia

Email: susiari.tantri@undiksha.ac.id
} 


\section{INTRODUCTION}

Oral literature works are literature works that are disseminated orally and inherited from one generation to the next generation (Sidik \& Putraidi, 2018). One type of oral literature works that is popular in Indonesia is folklore. By definition, folklore can be interpreted as a story that develops in the community of a particular area and is inherited orally. Furthermore, Danandjaja (in Hidayat et al., 2019) defined folklore as a form of oral literary work that emerges and develops from a traditional society that is spread out in a relatively unchanging form using cliché language. Folklore is a form of cultural diversity in every region in Indonesia, representing Indonesia as a multicultural country (Wiguna \& Alimin, 2018). Generally, folklore tells about an event at a place or the origin of a place. The characters displayed in folklore are not only human, but they can also be in the form of animals or gods (Gusnetti et al., 2015).

Folklore has several characteristics, including (1) being inherited from one generation to the next generation, (2) the author is unknown (anonymous), (3) contains noble values and manners, (4) traditional, (5) has many variations and versions, (6) the forms are clichéd in their arrangement or way of expression, (7) developing by word of mouth, and (8) delivered orally (Saputra, in Hidayat et al., 2019). Apart from its function as an entertainer, folklore can also shape the character of the reader. This was also conveyed by Kusmayadi et al. (2017), folklore contains emotions, aesthetics, ethics, and logic that will lead to good moral character education for its readers.

A moral is a truth value shaped from social behavior around an environment where a community lives (Nurdyansyah, in Qur'ani \& Andalas, 2019). Furthermore, Sulistyarini (in Habsari, 2017) stated that folklore has noble values of a nation, especially character values and moral lessons. If folklore is studied in terms of moral values, it can be classified into individual moral values, social moral values, and religious moral values. Individual moral values include obedience, willingness to sacrifice, courage, honesty, respect, fairness and wisdom, hard work, keeping promises, understanding reciprocity, being humble, and aware behaved. Social moral values include cooperation, being helpful, compassionate, harmony and peace, giving advice, caring for others, and like to pray for others. Meanwhile, religious moral values include believing in God's power, believing in the existence of God, surrendering to God, and asking God for forgiveness.

The existence of folklore, which is one of the nation's wealth, has made folklore included in the learning curriculum in schools at Elementary Schools, Junior High Schools, and Senior High Schools. Danadjaja (in Purnama, 2019) also strengthened this phenomenon. According to him, folklore is a part of Indonesian culture with many ideas and is rich in values that are beneficial to national development. Siswanto (2017) revealed that literature learning (including folklore) in the 2013 Curriculum is designed as education through literature itself. The 2013 Curriculum that is currently used integrates language and literature learning with moral character education. Therefore, all the competencies contained in the 2013 Curriculum are used to develop student morale.

The rapid development of technology has many impacts on human life. The era of technological development has now reached the 4.0 industrial revolution. The period of the industrial revolution 4.0 is signed by digital trade (e-commerce), artificial intelligence, big data, and the use of robots (Prasetiantono, in Abdullah, 2019). The industrial revolution 4.0 is a technological advancement that collaborates the physical, biological, and digital areas (Hamdan, 2018). Folklore has received the impact of many advances that have been made by the 4.0 industrial revolution in human life. An example is the media for telling folklore are getting easier and more interesting. Initially, folklore was only conveyed orally. However, thanks to advances in technology, nowadays folklore can be conveyed in an audio-visual form via the Youtube platform.

Dongeng Kita is a Youtube channel that broadcasts folklore, produced by Kastari Animation (PT Kastari Sentra Media). The channel was established on January $30^{\text {th }}, 2017$. As of March $9 t^{\text {th }}, 2021$, Dongeng Kita already has 1.78 million followers, with approximately 219.4 million views. The channel not only broadcasts folklore from Indonesia but also folklore from various countries. 


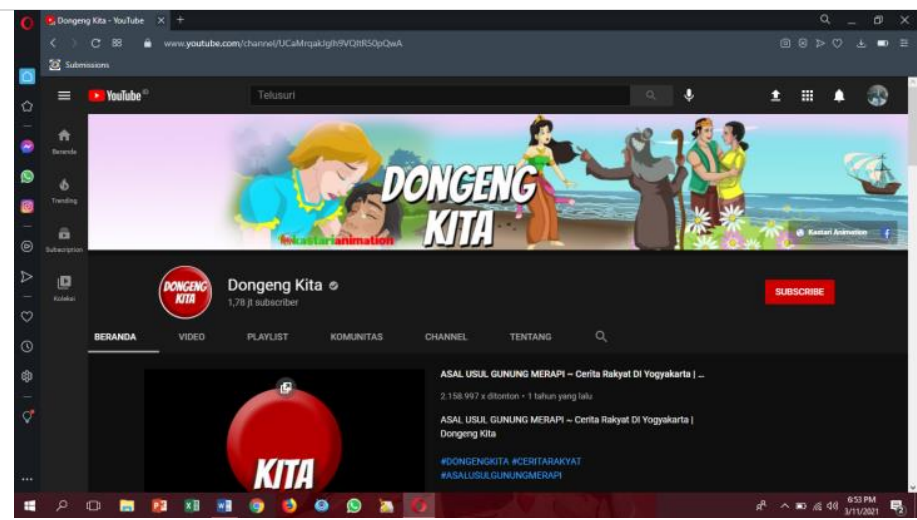

Figure 1. Dongeng Kita Channel Display

(source: https://www.youtube.com/channel/UCaMrqakJglh9VQItR5opQwA)

The existence of the Dongeng Kita channel has several exciting things to be identified to enrich the knowledge of oral literature and moral education, especially in connection with the analysis of the relevance of this videos channel to Indonesian learning. Therefore, this research analyzed the moral values in the Dongeng Kita channel and its relevance to folklore learning in schools. The reasons for choosing the folklore videos of Dongeng Kita channel as research material in this research are as follows. First, few studies were examining the videos on the Dongeng Kita channel. Second, the researchers wanted to introduce folklore in Dongeng Kita channel to a broader community and provide a reference to education practitioners and informed that the Dongeng Kita channel could also be used as a media for learning folklore in schools. Third, folklore in the Dongeng Kita channel contains many moral values that readers can receive as life lessons.

Similar researches have been done namely Rachmawati's (2018) research titled Nilai-nilai Pendidikan dalam Cerita Rakyat Bima La Bango Versi Muhammad Tahir Alwi dan Relevansinya dengan Pembelajaran Sastra di SMP, as well as research by Siregar et al. (2020) titled Nilai Pendidikan Karakter dalam Cerita Rakyat Nias dan Potensinya sebagai Materi Pembelajaran Sastra di SMA. Rachmawati's research found that the folklore of La Bango by Muhammad Tahir Alwi has religious education values, moral education values, and social education values. Besides, this folklore has relevance to learning, because moral values can support Indonesian learning in the 2013 Curriculum. Meanwhile, Siregar's research found that the value of character education in Nias folklore is a religious value, good personality, social concern, honesty, and hard work. Nias folklore can also be used as a learning resource in high school because it can shape the student characters. The difference between this research and the two existing studies lies in the subject. Previous research subjects were still analyzing folklore in text form, while this research studied folklore in audio-visual form.

\section{METHODS}

The design of this research was descriptive-qualitative. Qualitative research produces data in written or spoken words (Siyoto \& Sodik, 2016). Meanwhile, descriptive research is research conducted by describing the variables (Kuntjojo, 2009). Descriptive-qualitative research used to describes the moral values in the folklore videos on the Dongeng Kita channel. In addition, the moral values relevance to Indonesian learning at grade VII of Junior High School is also described. The grade VII was chosen because folklore learning was studied in this level.

The data source in this research is the Dongeng Kita channel, with data in the form of videos of folklore which were randomly selected as many as six videos. The video titles are Legenda Joko Kendil, Asal Usul Gunung Batu Benawa, Ande-Ande Lumut, Bawang Merah Bawang Putih, Legenda Gunung Kelud, and Roro Jonggrang. The videos were chosen because they were considered capable of providing various moral values. The data collection methods used are digital observation and documentation. Digital observations were conducted to see Dongeng Kita channel circumstances. Meanwhile, the documentation is performed to determine the relevance of Dongeng Kita channel 
videos to the grade VII Indonesian learning contained in the syllabus. The data analysis technique used in this research was Miles and Huberman model. The elements contained in the model include (1) data reduction, (2) data presentation, and (3) conclusions/verification (Nugrahani \& Al-Ma'ruf, 2015).

Data reduction is accomplished by selecting the main things that focus on this research and removing unnecessary data. Data presentation is an attempt to display information that has been compiled. Data presentation was conducted by presenting a description of the moral values of the Dongeng Kita channel videos and its relevance to Indonesian learning. Concluding is an activity to formulate conclusions based on the data obtained. Hence, after the data is presented and accepted, a conclusion is drawn.

\section{FINDING AND DISCUSSIONS}

\section{Moral Values in Dongeng Kita Channel Videos}

Based on the analysis that has been conducted on six folklore videos on the Dongeng Kita channel, there are eight moral values which are identified, namely respect for others (social values), not being disobedient to parents (individual values), being honest (individual values), not being lazy (individual values), not being bad (social values), not being greedy (individual values), keeping promises (individual values), and not cheating (individual values). The following is an analysis of moral values.

Table 1. Moral Values in Dongeng Kita Channel Videos

\begin{tabular}{|c|c|c|c|}
\hline No & Title & Moral Values & Quotation \\
\hline 1 & $\begin{array}{l}\text { Legenda Joko } \\
\text { Kendil }\end{array}$ & $\begin{array}{l}\text { Respect for others } \\
\text { (social value) }\end{array}$ & $\begin{array}{l}\text { Joko Kendil won a competition and } \\
\text { married Putri Melati, but Putri } \\
\text { Melati's sisters always insulted Joko } \\
\text { Kendil because of his ugly face. } \\
\text { Finally, the curse of Jaka Kendil } \\
\text { disappeared and his face became } \\
\text { handsome, because he found } \\
\text { someone who sincerely loved him. } \\
\text { Putri Melati's sisters were regret. }\end{array}$ \\
\hline 2 & $\begin{array}{l}\text { Asal Usul } \\
\text { Gunung Batu } \\
\text { Benawa }\end{array}$ & $\begin{array}{l}\text { Not disobedient } \\
\text { to parents } \\
\text { (individual value) } \\
\text { and being honest } \\
\text { (individual value) }\end{array}$ & $\begin{array}{l}\text { Panganten and his mother had a } \\
\text { hard life in the village. Panganten } \\
\text { went to another place to change his } \\
\text { fate. From the outcome of his } \\
\text { honesty in selling, finally Panganten } \\
\text { became a rich person. On the other, } \\
\text { he did not want to confess to his } \\
\text { mother until she cursed him to be a } \\
\text { stone. }\end{array}$ \\
\hline 3 & $\begin{array}{l}\text { Ande-Ande } \\
\text { Lumut }\end{array}$ & $\begin{array}{l}\text { Not being lazy } \\
\text { (individual value) } \\
\text { and not being bad } \\
\text { (social value) }\end{array}$ & $\begin{array}{l}\text { Klenting Kuning is a royal princess } \\
\text { in disguise. Klenting Kuning was } \\
\text { adopted by a widow who had three } \\
\text { daughters. The three widow's } \\
\text { daughters were very lazy and } \\
\text { treated Klenting Kuning as a maid. } \\
\text { After the identity of Klenting } \\
\text { Kuning was discovered, her } \\
\text { adoptive family regretted it. }\end{array}$ \\
\hline
\end{tabular}




\begin{tabular}{|c|c|c|c|}
\hline 4 & $\begin{array}{l}\text { Bawang Merah } \\
\text { Bawang Putih }\end{array}$ & $\begin{array}{l}\text { Not being greedy } \\
\text { (individual value) } \\
\text { and not being bad } \\
\text { (social value) }\end{array}$ & $\begin{array}{l}\text { Bawang Putih had a stepmother and } \\
\text { a half-sister named Bawang Merah. } \\
\text { Bawang Merah and her mother } \\
\text { were always bad to Bawang Putih } \\
\text { and controlled Bawang Putih } \\
\text { property. The viciousness of } \\
\text { Bawang Merah and her mother } \\
\text { finally ended because they were } \\
\text { killed by a snake. }\end{array}$ \\
\hline 5 & $\begin{array}{l}\text { Legenda } \\
\text { Gunung Kelud }\end{array}$ & $\begin{array}{l}\text { Keeping promises } \\
\text { (individual value) }\end{array}$ & $\begin{array}{l}\text { The King of Brawijaya held a contest } \\
\text { in which the prize was to marry his } \\
\text { daughter, Princess Diah. However, } \\
\text { because the winner of the } \\
\text { competition was Lembu Sura who } \\
\text { had a buffalo head, the king and his } \\
\text { daughter broke their promise and } \\
\text { killed Lembu Sura. Before he died, } \\
\text { Lembu Sura gave a curse to the } \\
\text { kingdom of King Brawijaya in the } \\
\text { form of a volcano. }\end{array}$ \\
\hline 6 & $\begin{array}{l}\text { Roro } \\
\text { Jonggrang }\end{array}$ & $\begin{array}{l}\text { Not cheating } \\
\text { (individual value) }\end{array}$ & $\begin{array}{l}\text { Bandung Bondowoso fell in love } \\
\text { and wanted to marry Roro } \\
\text { Jonggrang. Because she didn't want } \\
\text { to, Roro Jonggrang gave Bandung } \\
\text { Bondowoso a requirement to build a } \\
\text { thousand temples. Seeing that the } \\
\text { construction of the temple was } \\
\text { almost complete, Roro Jonggraang } \\
\text { cheated which made Bandung } \\
\text { Bondowoso angry and cursed her to } \\
\text { be the thousandth temple. }\end{array}$ \\
\hline
\end{tabular}

\section{Moral Value of Respect for Others}

Respect for others (tolerance) is one of the attitudes that all people must own because diversity cannot be separated from human life. The variety that exists in Indonesia is among the ethnicities, languages, customs, cultures, and beliefs (Hadi et al., 2017). Mutual respect is needed to maintain unity, understanding others, and cherish fellow human beings. The moral values of respect for others in the Legenda Joko Kendil story are presented in the part of Putri Melati's sisters, who always insulted Joko Kendil for having an ugly appearance but finally stopped when Joko Kendil became handsome. The bad character of Putri Melati's sisters certainly cannot be imitated since each person is created differently by God.

If it is related to the current condition in Indonesia, mutual respect must be more actively raised in the younger generation. Apriliani (2019) stated that currently, intolerance in Indonesia continues to emerge and violates the motto "Bhinneka Tunggal Ika". The forms of intolerance include religious discrimination, ethnic discrimination, and political polemics. Therefore, the moral values of mutual respect in the legend of Joko Kendil can support moral cultivation. The forms of mutual respect that can be applied are respecting each other, not insulting others, not disturbing others, etc. 


\section{Moral Value of Not Being Disobedient to Parents}

According to Andani (2016), as parents' child, every child should devote parents to caring and educating their child since childhood. The moral value of not being disobedient to parents is found in the Asal Usul Gunung Batu Benawa story. In this story, it is described that the disobedient son (Panganten) got a curse to become a stone. This is a parable in the real world, that iniquity will be responded to by God.

In Indonesia, the incident of a child's iniquity is usual. In 2019, a boy in Surabaya kicked his mother's head for the sake of money (Utomo, 2019). Besides, in 2020, a girl kicked and hit her mother because her mother had been preparing her child's clothes for a long time (Petrus, 2020). Based on these two events, the formation of a young generation with obedient morals is needed to create a better life. One of the ways is to take a moral value from the Asal Usul Gunung Batu Benawa story.

\section{Moral Value of Being Honest}

Honesty is an attitude that shows something as it is, not lying to others, not exaggerating nor subtracting information, and not hiding the truth (Suparman, in Ungusari, 2015). Honesty moral value are found in the Asal Usul Gunung Batu Benawa story. In this story, it is told that Panganten was an honest seller. Because of his honesty, he can be a successful person. This is of course, the same as the adage that "honesty is a currency that applies everywhere."

Lazuardi (in Chairilsyah, 2016) stated that there are several benefits of honesty, such as feeling and having a calm heart, getting a reward, respecting others, and having many friends. The disadvantage of not being honest is an anxious heart, being sinful, being disrespected by others, and not having many friends. Therefore, everyone must have an honest attitude. And keep in mind that one of the keys to success is honesty.

\section{Moral Value of Not Being Lazy}

Zaques (in Suharwati, 2019) defined laziness as reluctance to do what should be done. The moral value of not being lazy is found in Ande-Ande Lumut's story. In this story, Klenting Kuning's sisters are very lazy and treated Klenting Kuning as a maid. This is an act that is not praiseworthy because laziness will bring failure. Imam Ibnul Qoyyim (in Fitria, 2020) stated that laziness would lead to wasting excessive time, so that lazy people get nothing, apart from regret. Therefore, laziness is a trait that must be avoided because it can hinder success.

\section{Moral Value of Not Being Bad}

In the Indonesian Dictionary, being bad is defined as very bad or unkind behavior, character, or deed. The moral value of not doing bad is found in the story of Ande Ande Lumut and Bawang Merah Bawang Putih. Darmasya (2014) stated that people who do bad things get a punishment commensurate with the crime they have committed. Darmasya's statement has been shown clearly in the two stories.

In Ande-Ande Lumut's story, it is stated that in the end, the adoptive family of Klenting Kuning regretted knowing that the Klenting Kuning whom they had been treating so badly was a royal princess. In Bawang Merah Bawang Putih, it is stated that Bawang Merah and his mother died because of their viciousness. Referring to these two examples, everyone should not do bad things to others because the bad people will be responded, and bad actions will end in regret.

\section{Moral Value of Not Being Greedy}

Greed is one of the bad things that must be avoided. Frassiska (2019) stated that greed is an act that represents how someone wants something excessively without thinking about the consequences. Greed only benefits one side and can harm others. A clear example of greed that exists in Indonesia is corruption. According to Treisman (in Pradiptyo, 2016), corruption is the misuse of public resources for individual interests. Corruption itself has many negative impacts, such as the loss of rights of people in need, decreased trust in the government, and the lack of progress in a country. Therefore, no one likes people with a greedy attitude. The moral values of not being greedy that is found in the story of Bawang Merah Bawang Putih are very detailed and can provide education to the viewers. 
Moral Value of Keeping Promises

Keeping promises is a key performance indicator in a mandate. Besides, keeping promises will show a person's level of trustworthiness in carrying out responsibility (Tasmara, in Herianingrum et al., 2015). The moral value of keeping promises is found in the Legenda Gunung Kelud story. In this story, it is stated that the Kingdom of King Brawijaya received a curse in the form of a volcano that would erupt because of his actions that did not occupy a promise to Lembu Sura.

Based on the Legenda Gunung Kelud story, it can be agreed that keeping promises is one of the characteristics that must be possessed, to be trusted by others and so as not to harm oneself. Examples that can be done to occupy a promise include doing what has been truly agreed, not betraying to others, completing the mandate well, and being loyal to loved ones.

\section{Moral Value of Not Cheating}

Matompo (2020) stated that cheating is generally done because people want to get big profits. However, unfair only benefits the person who commits it and will hurt other people. This is almost the same as being greedy. The moral value of not cheating is found in the story of Roro Jonggrang. In the story, Roro Jonggrang cheated by tricking Bandung Bondowoso, who was building a thousand temples. Because of that, Roro Jonggrang was cursed to be the thousandth temple.

Cheating is classified into 3 parts, namely cheating in buying and selling, cheating in knowledge, and cheating in speech (Gunarsa, 2021). To be sure of the three types, all are bad things that must be avoided. The bad effects of cheating include giving a bad self-image, being sinful, and creating disunion. It needs to be applied in ourselves that good hard work is hard work without cheating.

\section{Relevance to Indonesian Learning in Schools}

Folklore material exists in Indonesian learning at the level of Junior High School, grade VII, especially in $1^{\text {st }}$ semester. One of the competency standards is "concludes the characteristics of the elements of folklore (legend or fable) that are read/listen." The aspect indicators of learning are as follows.

a. Cognitive Aspect. Cognitive aspect are related to the reasoning and thinking processes of students in receiving knowledge (Retno, 2017). In this case, students will identify characteristics of the elements of folklore (legend or fable) and show it.

b. Psychomotor Aspect. Psychomotor aspect are aspect related to skills involving students' muscular and psychological nervous system (Kasenda et al., 2016). In this case students will be invited to express opinions (findings) of characteristics of the elements of folklore (legend or fable) that have been observed.

c. Affective Aspect. The affective aspect is an aspect of students' feelings (MAN 1 Bengkalis Teacher Team, 2020). It takes responsibility, honesty, and a sense of care between students in learning. In this case, students must have a sense of care and be willing to help friends who are experiencing difficulties. In addition, students must have the awareness to carry out the exercises honestly and responsibly.

Based on the indicators and aspects above, then the folklore learning design is presented using learning media in the form of Dongeng Kita channel. This learning design has been adjusted to the implementation of distance learning in the COVID-19 pandemic situation. The application used as a class is the WhatsApp Group with a time allocation of 2x40 minutes. The sample of the video used is Asal Usul Gunung Batu Benawa. 
Table 2. Folklore Learning Design

\begin{tabular}{|c|c|c|}
\hline 1 & Competency Standard & $\begin{array}{l}\text { Concludes the characteristics of the elements of } \\
\text { folklore (legend or fable) that are read/listen. }\end{array}$ \\
\hline 2 & Basic Competency & $\begin{array}{l}\text { Find characteristics of the elements of folklore } \\
\text { (legend or fable) that are read/listen. }\end{array}$ \\
\hline 3 & Indicator & $\begin{array}{l}\text { Being able to conclude the characteristics of the } \\
\text { elements of folklore (legend or fable) that are } \\
\text { read/listen. }\end{array}$ \\
\hline 4 & Learning Objective & $\begin{array}{l}\text { Students can find characteristics of the elements of } \\
\text { folklore (legend or fable) that are read/listen. }\end{array}$ \\
\hline 5 & Learning Material & $\begin{array}{l}\text { Folklore (Legend) of Asal Usul Gunung Batu } \\
\text { Benawa }\end{array}$ \\
\hline 6 & Learning Methods & $\begin{array}{l}\text { Problem-based learning, active student learning, } \\
\text { and assignments }\end{array}$ \\
\hline 7 & Learning Media & $\begin{array}{l}\text { Dongeng Kita Youtube channel and WhatsApp } \\
\text { Group }\end{array}$ \\
\hline 8 & $\begin{array}{l}\text { Learning Activity Steps } \\
\text { a. Opening Activity (1 } \\
\text { 1. The teacher opens } \\
\text { 2. The teacher motiv } \\
\text { 3. The teacher delive } \\
\text { b. Main activity ( } 55 \mathrm{~m} \\
\text { 1. Teacher gives Yout } \\
\text { 2. The teacher asks s } \\
\text { 3. The teacher asks tl } \\
\text { 4. The teacher discu } \\
\text { (legend) in the vid } \\
\text { 5. Teacher and stude } \\
\text { c. Closing activity (15 } \\
\text { 1. The teacher asks s } \\
\text { 2. The teacher gives } 1 \\
\text { 3. Teacher gives rein } \\
\text { 4. The teacher gives } \\
\text { folklore (legend or } \\
\text { 5. The teacher closes }\end{array}$ & $\begin{array}{l}\text { O minutes) } \\
\text { the class } \\
\text { tes and appreciates students } \\
\text { s the learning objective and benefits } \\
\text { inutes) } \\
\text { ube link of Asal Usul Gunung Batu Benawa } \\
\text { udents to watch the video } \\
\text { ne students' perception of the video } \\
\text { ss the characteristics of the elements of folklore } \\
\text { eo with students } \\
\text { nt conduct question and answer session } \\
\text { minutes) } \\
\text { udents to concludes the learning } \\
\text { eaffirmation about the learning conclusion } \\
\text { orcement } \\
\text { tasks to identify characteristics of the elements of } \\
\text { fable) in other folklores in Dongeng Kita channel } \\
\text { the learning }\end{array}$ \\
\hline 9 & $\begin{array}{l}\text { Assessment } \\
\text { a. Individual task } \\
\text { b. Activity and cor }\end{array}$ & -0 \\
\hline
\end{tabular}

The Dongeng Kita Youtube channel in Indonesian learning during the COVID-19 pandemic is one of the innovations. Because, generally learning in schools has turned into assignments. This is the same as Santoso's (2020) statement that the current way of learning is very boring because the teacher gives assignments without providing material explanations. The Dongeng Kita folklore has relevance to the learning objectives, which can be used as a learning media. Besides, the moral values contained will also greatly support the achievement of learning competencies in the 2013 Curriculum, aiming to develop student morale.

The correlation of moral values contained in the moral formation of students is as follows. First, the moral values of mutual respect can form a younger generation that is tolerant of differences. Second, moral values that are not disobedient for parents can form a young generation who love their parents. Third, the moral values of being honest can form a young generation who always uphold honesty. Fourth, moral values are not lazy to form a young generation who is always enthusiastic. Fifth, the moral value of not doing bad things can form a kind young generation. Sixth, moral values of not being greedy can form a young generation that is anti-corruption. Seventh, the moral values that keep promises can form a trustworthy young generation. And finally, the moral value of not cheating can shape a young generation who is always fair. 


\section{CONCLUSION}

The folklore videos on the Dongeng Kita Youtube channel have good moral values for the viewers. Based on the analysis of the six videos, it was found several moral values, namely respect for others, not being disobedient to parents, being honest, not being lazy, not being bad, not being greedy, keeping promises, and not cheating. Besides, the moral values have relevance in Indonesian learning for grade VII, Junior High Schools, because the moral values can be used as learning media and will greatly support the achievement of learning competencies in the 2013 Curriculum, which aims to develop student morale. For teachers, it is expected that the Dongeng Kita channel can be a learning media to make learning more enjoyable. For further research, it is expected to conduct similar research with different variables to enrich of oral literature and moral education field in Indonesia.

\section{REFERENCES}

Abdullah, F. (2019). Fenomena Digital Era Revolusi Industri 4.o. Jurnal Dimensi DKV Seni Rupa dan Desain, 4(1). DOI: http://dx.doi.org/10.25105/jdd.v4i1.4560.

Andani, L. (2016). Analisis Komparatif Nilai Pendidikan dalam Legenda Malin Kundang dan Pulau Paku. Skripsi. Tanjungpinang: Universitas Maritim Raja Ali Haji.

Apriliani, D. P. (2019). Ada Apa dengan Toleransi di Indonesia? Retrieved from http://news.unair.ac.id/2019/11/19/ada-apa-dengan-toleransi-di-indonesia/.

Chairilsyah, D. (2016). Metode dan Teknik Mengajarkan Kejujuran pada Anak Sejak Usia Dini. Jurnal Educhild, 5(1), 8-14. DOI: http://dx.doi.org/10.33578/jpsbe.v5i1.3822

Darmasya, M. W. (2014). Pengulangan Kejahatan atau Residiv (Analisi Kriminologis dan Sosiologis di Lembaga Permasyarakatan Kelas I Makassar 2008-2014). Skripsi. Makassar: UIN Alauddin Makassar.

Dongeng Kita. Retrieved from https://www.youtube.com/channel/UCaMrqakJglh9VQItR5opQwA.

Fitria, D. E. (2020). Bahaya "Malas dan Sombong" dalam Agama Islam. Retrieved from http://farmasi.unida.gontor.ac.id/2020/o1/22/bahaya-malas-dan-sombong-dalam-agamaislam/.

Frassiska, M. (2019). Peningkatan Hasil Belajar Akidah Akhlak Materi Akhlak Tercela (Pesimis, Bergantung, Serakah, dan Putus Asa) melalui Model Cooperatif Scriors di Kelas V MI Darrussa'adah Karang Tumpuk Panceng Gresik. Skripsi. Surabaya: UIN Sunan Ampel Surabaya.

Gunarsa, A. K. R. (2021). Perbuatan Curang, Faktor dan Dampaknya. Retrieved from https://muslim.or.id/22590-perbuatan-curang-faktor-dan-dampaknya.html.

Gusnetti et al. (2015). Struktur dan Nilai-nilai Pendidikan dalam Cerita Rakyat Kabupaten Tanah Datar Provinsi Sumatera Barat. Jurnal Gramatika: Jurnal Pendidikan Bahasa dan Sastra Indonesia, 1(2). DOI: 10.22202/jg.2015.v1i2.1238.

Habsari, Z. (2017). Dongeng Sebagai Pembentukan Anak. Jurnal Kajian Perpustakaan dan Informasi, 1(1), 21-29. DOI: 10.17977/umoo8v1i12017po21.

Hadi, D. W., et al. (2017). Analisis Faktor-faktor yang Memengaruhi Sikap Toleransi di Indonesia. Jakarta: Kementrian Pendidikan dan Kebudayaan.

Hamdan. (2018). Industri 4.o: Pengaruh Revolusi Industri pada Kewirausahaan demi Kemandirian Ekonomi. Jurnal Nusamba, 3(2). DOI: 10.29407/nusamba.v3i2.12142.

Herianigrum, S., et al. (2015). Implementasi Nilai-nilai Amanah pada Karyawan Hotel Darussalam Pondok Pesantren Gontor di Ponorogo. Jurnal At-Tijarah, 5(1). DOI: 10.21111/tijarah.v1i1.382.

Hidayat, W. A., et al. (2019). Struktur dan Fungsi Cerita Rakyat Benayuk Versi Desa Sepalang Dalung Kabupaten Tana Tidung: Kajian Strukturalisme Naratologi. Jurnal Ilmu Budaya, 3(4). DOI: http://dx.doi.org/10.5281/ilmubudaya.v3i4.2383.

Kasenda, L. M., Sentinuwo, S., \& Tulenan, V. (2016). Sistem Monitoring Kognitif, Afektif dan Psikomotorik Siswa Berbasis Android. Jurnal Teknik Informatika, 9(1). DOI: https://doi.org/10.35793/jti.9.1.2016.14808 
Indonesian Dictionary by The Language Center of The Ministry of Education and Culture.

Kuntjojo. (2009). Metodologi Penelitian. Kediri:

Kusmayadi, et al. (2017). Pengembangan Multimedia Cerita Rakyat sebagai Penumbuhan Karakter Siswa. Jurnal Pendidikan: Teori, Penelitian, dan Pengembangan, 2(7). DOI: http://dx.doi.org/10.17977/jptpp.v2i7.9630.

MAN 1 Bengkalis Teacher Team. (2020). Kognitif, Afektif, dan Psikomotorik Menurut Bloom. Retrieved from www.manıbengkalis.sch.id/kognitif-afektif-dan-psikomotorik-menurut-bloom.

Matompo, O. S. (2020). Efektivitas Penerapan Sanksi Hukum terhadap Persaingan Curang dalam Pelelangan Pekerjaan di Kota Palu. Maleo Law Journal, 4(1). DOI: -.

Nugrahani, F., \& Al-Ma'ruf, I. A. (2015). Metode Penulisan Karya Ilmiah. Yogyakarta: Nuansa Aksara. Petrus, A. (2020). Peserta Audisi The Voice Indonesia 2019 Pukul dan Tendang Ibu Kandung. Retrieved from https://m.merdeka.com/peristiwa/trianetha-peserta-audisi-the-voiceindonesia-2019-pukul-dan-tendang-ibu-kandung.html.

Pradiptyo, R. (2016). Dampak Sosial Korupsi. Jakarta: Komisi Pemberantasan Korupsi.

Purnama, Y. (2019). Pentingnya Kebudayaan Indonesia Lewat Cerita Rakyat sebagai Media Pembelajaran. Retrieved from www.smktarunabangsa.sch.id/artikel/detail/pentingnyakebudayaan-indonesia-lewat-cerita-rakyat-sebagai-media-pembelajaran.

Qur'ani, H. B., \& Andalas, E. F. (2019). Nilai Moral Cerita Rakyat di Banten. Jurnal Basastra, 8(2). DOI: $10.24114 /$ bss.v8i3.15885.

Rachmawati, F. (2018). Nilai-nilai Pendidikan dalam Cerita Rakyat Bima La Bango Versi Muhammad Tahir Alwi dan Relevansinya dengan Pembelajaran Sastra di SMP. Skripsi. Lombok: Universitas Mataram.

Retno, D. (2017). Kognitif, Afektif, dan Psikomotorik menurut Bloom: Perkembangan dan Peranan. Retrieved from www.dosenpsikologi.com/kognitif-afektif-dan-psikomotorik-menurut-bloomperkembangan-dan-peranan.

Santoso, S. (2020). Kegiatan Belajar Bersama Angkring Sinau Sebagai solusi Pengondisian Belajar Aktif dan Kreatif di Tengah Pandemi Covid-19. Civics Education and Social Sciense Journal (CESSJ), 2(2). DOI: https://doi.org/10.32585/cessj.v2i2.1133.

Sidik, A. S., \& Putraidi, K. (2018). Cerita Rakyat dan Relevansi Pendidikan Karakter sebagai Upaya Pengikisan Deklinasi Moral (Sebuah Kajian Antropologi Sastra). Prosiding Seminar Nasional Lembaga Penelitian dan Pendidikan (LPP) Mandala.

Siregar, E. F., et al. (2020). Nilai Pendidikan Karakter dalam Cerita Rakyat Nias dan Potensinya sebagai Materi Pembelajaran Sastra di SMA. Kode: Jurnal Bahasa, 9(4). DOI: http://dx.doi.org/10.1234/.voio.381.

Siswanto, W. (2017). Pengantar Teori Sastra. Sleman: Aditya Media Publishing.

Siyoto, S., \& Sodik, M. A. (2016). Dasar Metodologi Penelitian. Yogyakarta: Literasi Media Publishing. Suharwati. (2019). Faktor-faktor Kemalasan Peserta Didik Mengikuti Pembelajaran Senam Lantai di SD Negeri Menter II Kecamatan Tanjungsari Kabupaten Gunungkidul. Skripsi. Yogyakarta: Universitas Negeri Yogyakarta.

Ungusari, E. (2015). Kejujuran dan Ketidakjujuran Akademik pada Siswa SMA yang Berbasis Agama. Naskah Publikasi. Surakarta: Universitas Muhammadiyah Surakarta.

Utomo, D. P. (2019). Viral Anak Tendang Kepala Ibu, Gara-garanya Tak Diberi Uang Rp 10 Ribu. Retrieved from https://news.detik.com/berita-jawa-timur/d-4675756/viral-anak-tendangkepala-ibu-gara-garanya-tak-diberi-uang-rp-10-ribu.

Wiguna, M. Z., \& Alimin, A. A. (2018). Analisis Nilai-nilai Moral dalam Cerita Rakyat Kalimantan Barat. Jurnal Pendidikan Bahasa, 7(1). DOI: http://dx.doi.org/10.31571/bahasa.v7i1.833. 